technique has become clinical practice, ethical discussions belatedly commence and that is too late. This is what happened in Sweden when prenatal diagnosis was introduced.

The author concludes by saying that "it must be considered to be a main core of the work-ethics of any scientific or technological specialty that specialists have a strong responsibility to lay ground for, initiate and participate in such discussions".

My conclusion is that the author has written an important work which describes and analyses the implicit moral values of medical specialists in Sweden during the introduction of prenatal diagnosis. I believe his findings can be generalised to other countries and that they show the importance of discussing ethical issues at an early stage in the introduction of a new technique or technology.

JAN ARLEBRINK

Faculty of Medicine and Department of Theology and Religious Studies,

Lund University, Sweden

\section{Christian Virtues in Medical Practice}

\author{
Edmund D Pellegrino and David C \\ Thomasina, Washington DC, \\ Georgetown University Press, 1996, \\ $164+x i i$ pages, $£ 21.75$, \$27.95.
}

The authors say of this book that it "attempts to define the Christian virtues of faith, hope and charity and to show how they modify the practice of medicine and the healing professions and the ethical principles of benevolence, autonomy and justice". These, together with non-maleficence (which the authors regard as too minimal to warrant consideration) have been much discussed in recent years in medical ethics, notably in what has become a standard book, Principles of Bioethics by Beauchamp and Childress. The authors of Christian Virtues in Medical Practice are two American Roman Catholics: Pellegrino is a wellknown medical specialist and ethicist, and Thomasina a philosopher with clinical interests. This is the latest of a series of collaborations by them. They say that medical ethics has expanded more rapidly in the last 20 years than in the whole of the previous 2,500 years, and also that the golden age of specific medicine has just begun.
In this dynamic situation the practice of medicine is carried on in the "West" in plural societies, hence the effort to arrive at some agreed basic principles. The authors are convinced that the many Christians involved in the practice of medicine must be engaged in serious ethical discussion with those of other faiths and philosophies engaged in medical practice. They must show courtesy and respect for them; dogmatism and proselytising with respect to colleagues or patients must be ruled out, for it does not respect them as persons. At the same time the preoccupation of the authors is with what Christianity can contribute to ethical issues in medical practice. What can it add to the natural virtues of benevolence, autonomy and justice and the concomitant truth-telling, promisekeeping and confidentiality which follow from them? How can faith, hope and charity inform the ethical discernment of Christians? The relation is bound to be subtle. However, charity can rule out things which are not subtle; rudeness, inaccountability, abruptness, refusal to treat for economic reasons, discrimination because of social class or ethnicity, medical practice regarded as a business, or as an exercise in entrepreneurship, applied biology, politics, or social convenience. These and other radical remarks would appear to call into question much public policy in the USA (and, of course, the UK), but the authors do not directly address these, confining their few remarks to Christian hospitals.

In the middle chapters of the book they write cogently on the greater depth which the three theological virtues of faith, hope and charity add to the natural virtues of benevolence, autonomy and justice. They make full allowance for the fact that these virtues can be expressed by nonbelievers and that believers by no means always embody them, whilst maintaining their radicality and their call to a perfection which cannot be fully achieved but which nevertheless challenges and inspires. The book is not for the most part concerned with the substance of ethical decisions, but with the manner of arriving at them. The aim of the moral life is indeed to make the right decisions, but also to be a person of discernment and right motivation, for moral judgment is an art. This book is mostly concerned with the latter, with an ethic of virtue, with a Christian moral philosophy looking back in particular to St Augustine $\frac{C}{\Phi}$ and St Thomas Aquinas. An ethic of $\mathbb{Q}$ virtue can never be neglected, and $\$$ there has been considerable recent $\overrightarrow{\bar{D}}$. discussion of it both in moral philos- $?$ ophy and moral theology; and the latter must not ignore the former, as $\stackrel{\mathcal{O}}{\rightarrow}$ this book recognises. However, its discussion of moral philosophy will 흐 be too condensed for those unfamil- $\overline{\frac{\bar{T}}{}}$. iar with it. The basis of the book is $\widehat{\nabla}$ the Christian understanding of the dignity of the person, of which the कs writings of Pope John Paul II are sur- $\vec{\circ}$ prisingly taken as the key example, rather than some notable twentieth- $\vec{\omega}$ century personalist philosophers and $\stackrel{S}{S}$ theologians.

This brings me to a weakness in the book. It accepts without discussion $\omega$ the teaching of the Roman Catholic magisterium. It is one thing to accept o it, but another not to deal with criti- $\overrightarrow{0}$ cisms made of it by other Christians 을 and by many Roman Catholic moral theologians. The encyclical Veritatis Splendor (1993) is taken for granted. An absolute position is assumed on क abortion, euthanasia and several other $\vec{\theta}$ issues regarded as intrinsically evil $\stackrel{0}{6}$ acts, a conception which itseff. requires examination. No notice 9 taken of the position of Christia who would be grateful for large par of the book but who disagree with these absolute positions. Is it not $\frac{}{1}$ unwise to assume that once the magis- $\frac{\varrho}{2}$ terium has spoken critical moral $\overrightarrow{0}$ reason is suspended? Reception by the $\overline{3}$ faithful must in the long run be decisive with respect to the teaching of the church, as the example of Humanae Vitae on contraception has shown.

EMERITUS PROFESSOR THE REVD CANON $\stackrel{3}{-}$ RONALD PRESTON Professor of Social and Pastoral $₹$ Theology, Manchester University 의

The Moral Maze of Practice: a Stimulus for Reflection and Discussion

\author{
N Kohner, London, King's Fund \\ Publishing, 1996, 92 pages, $£ 8$.
}

This concise, affordable text, accu- $\stackrel{\mathbb{D}}{\overparen{D}}$ rately reflects its title. Amongst its $\mathbb{Q}$ intended readership of health care $\bar{\sigma}$ professionals it will be of immense value to clinically based nurses, 